\title{
The effect of cereal type and enzyme addition on pig performance, intestinal microflora, and ammonia and odour emissions
}

\author{
B. P. Garry, M. Fogarty, T. P. Curran, M. J. O'Connell and J. V. O'Doherty ${ }^{\dagger}$ \\ School of Agriculture, Food Science and Veterinary Medicine, University College Dublin, Lyons Research Farm, Newcastle, Co Dublin, Ireland
}

(Received 26 July 2006; Accepted 7 February 2007)

Two $2 \times 2$ factorial experiments were conducted to investigate the interaction between cereal type (wheat v. barley) and exogenous enzyme supplementation (with or without) on odour and ammonia emissions (experiment 1) and growth performance (experiment 2) in grower-finisher pigs. The enzyme supplement used contained endo-1, 3 (4) - $\beta$-glucanase (EC 3.2.1.6) and endo-1, 4 - $\beta$-xylanase (E.C 3.2.1.8). The diets were formulated to contain similar levels of net energy $(9.8 \mathrm{MJ} / \mathrm{kg}$ ) and lysine $(10.0 \mathrm{~g} / \mathrm{kg})$. The experimental treatments were as follows: (1) wheat-based diet, (2) wheat-based diet containing a $\beta$-glucanase and $\beta$-xylanase mixed enzyme supplement, (3) barley-based diet and (4) barley-based diet containing a $\beta$-glucanase and $\beta$ xylanase mixed enzyme supplement. In experiment 1, the diets were offered to the pigs for 23 days in sealed pens (eight pigs per pen) and this was repeated four times $(n=4)$. Odour and ammonia emissions were measured on days 9, 11, 14, 16, 21 and 23 of each replicate period. Odour samples were collected in 20-I Nalophan bags and analysed for odour concentration using an ECOMA Yes/No Olfactometer. Ammonia concentrations in the ventilation air were measured using Dräger tubes. In experiment 2 , 220 pigs were group fed in mixed sex pens using single-space feeders (11 pigs per feeder, six boars and five gilts) $(n=5)$. There was a cereal $x$ enzyme interaction in odour emission rates, ammonia emissions and selected microbial populations in the caecum and colon $(\mathrm{P}<0.05)$. The addition of an enzyme supplement to the barley-based diet increased both odour and ammonia emission, however the addition of an enzyme to the wheat-based diet decreased ammonia emission rates and had no effect on odour emission. Pigs offered the unsupplemented barley-based diet had a significantly $(\mathrm{P}<0.05)$ lower population of Enterobacteriaceae spp. and a higher population of Bifidobacteria spp. compared with enzyme-supplemented barley diets. However, there was no effect of enzyme supplementation in wheat-based diets. In the performance experiment, neither cereal type nor enzyme inclusion had an effect on pig performance or carcass characteristics. In conclusion, the inclusion of an enzyme mix to barley-based diets increased odour and ammonia emissions, while the addition of an enzyme mix to wheat-based diets decreased ammonia emissions.

Keywords: ammonia, cereals, enzymes, odour, pigs

\section{Introduction}

Long-term intensive pig production is associated with some negative effects on the environment with ammonia and volatile fatty acids (VFA) in the manure being significant sources of pollution. Ammonia contributes to nitrogen eutrophication and acidification (Pitcairn et al., 2002) while VFAs are associated with manure odours (Mackie et al., 1998).

Cereals are one of the major sources of dietary fibre in monogastric nutrition, however the composition of the fibre may vary depending on its source (De Lange, 2000).

\footnotetext{
${ }^{\dagger}$ E-mail: john.vodoherty@ucd.ie
}

Both wheat and barley contain anti-nutritional factors such as arabinoxylans and $\beta$-glucans. Elevated levels of these polysaccharides, in particular the soluble fraction, can cause an increase in digesta viscosity, preventing interaction between nutrients and digestive enzymes (Campbell and Bedford, 1992) and reducing nutrient digestibility (0'Connell et al., 2005). The addition of enzyme preparations can effectively degrade viscous non-starch polysaccharides (NSP) of the diet leading to a reduction in the viscosity of the diet and in enhanced nutrient utilisation (Dierick and Decuypere, 1996). However, the beneficial effects of fermentable fibre may be removed as a result of enzyme addition. Decreases in ammonia emission have 
been reported when sources of fermentable fibre are added to the diet (Canh et al., 1998) and $\beta$-glucans have been shown to have pre-biotic properties $\left(0^{\prime}\right.$ Connell et al., 2005). By increasing carbohydrate fermentation and limiting protein fermentation in the large intestine, the production of some of the most offensive VFAs can be reduced (Mackie et al., 1998; O'Connell et al., 2005). The hypothesis of this study was that the anti-nutritional effects of fermentable fibre in cereals would be removed through the addition of an enzyme to the diet and pig performance would improve. However the beneficial properties of fermentable fibre could also be removed resulting in a negative effect on intestinal microflora, and odour and ammonia emission.

\section{Material and methods}

\section{Experimental diets}

The experiments 1 and 2 were designed as a $2 \times 2$ factorial comprising four dietary treatments. The experimental treatments were as follows: (1) wheat-based diet, (2) wheat-based diet containing an enzyme supplement, (3) barley-based diet and (4) barley-based diet containing an enzyme supplement. The enzyme supplement was derived from Penicillium funiculosum (IMI SD 101) and contained endo $-1,3$ (4) $-\beta$ - glucanase (EC 3.2.1.6) and endo-1, 4- $\beta$-xylanase (EC 3.2.1.8) (European Council, 2001) only. The dietary composition and analysis of the diets is presented in Table 1. The diets were formulated to have identical concentrations of net energy $(9.8 \mathrm{MJ} / \mathrm{kg})$ and total lysine $(10 \mathrm{~g} / \mathrm{kg})$. All amino acid requirements were met relative to lysine (Close, 1994).

\section{Experiment 1: odour and ammonia emissions}

One hundred and twenty-eight (progeny of Large White $\times$ Landrace sows $\times$ Meatline boars) pigs (initial weight 58.9 (s.d 1.3) kg, final weight 88.5 (s.d. 2.1) kg) were used in four replicate experiments $(4 \times 32$ pigs $)$. In each replicate 32 pigs were blocked on the basis of live weight and within each block assigned to one of four treatments. Each treatment was offered in a sealed pen housing eight pigs (four boars and four gilts). The pigs were allowed a 14-day dietary adaptation period after which time they were weighed and transferred to the sealed pens (day 1). Each pen was designed using negative pressure ventilation and was fitted with a variable speed centrifugal fan and thermostatically controlled electrical radiant heater (Figure 1). The pens had separate air inlet and outlets and could be heated and ventilated independently. The ventilation rate was calculated by measuring the air flow from the pens using a Testo $400^{\mathrm{TM}}$ handheld monitoring device fitted with a vane anemometer. The ventilation rate in both pens was kept constant during the trials at approximately 48.3 (s.e. 1.3) $\mathrm{m}^{3} / \mathrm{h}$ per animal. The internal temperature in the house was kept constant at approximately 19.0 (s.e. 0.32$)^{\circ} \mathrm{C}$. The pens were partially slatted $(30: 70$

Table 1 Composition and analysis of experimental diets used in experiments 1 and 2

\begin{tabular}{|c|c|c|c|c|}
\hline & \multicolumn{4}{|c|}{ Treatment } \\
\hline & Wheat - enzyme & Wheat + enzyme & Barley - enzyme & Barley + enzyme \\
\hline \multicolumn{5}{|l|}{ Ingredient (g/kg) } \\
\hline Wheat & 704.6 & 704.6 & 0.00 & 0.00 \\
\hline Barley & 0.00 & 0.00 & 664 & 664 \\
\hline Soya-bean meal & 264.7 & 264.7 & 275.1 & 275.1 \\
\hline Soya-bean oil & 5.7 & 5.7 & 35.9 & 35.9 \\
\hline Vitamins and minerals & 25.0 & 25.0 & 25.0 & 25.0 \\
\hline \multicolumn{5}{|l|}{ Analysis } \\
\hline Xylanase activity (AXC/g) & 0.00 & 1370 & 0.00 & 1450 \\
\hline$\beta$-glucanase activity (AGL/g) & 0.00 & 1940 & 0.00 & 2090 \\
\hline Dry matter $(\mathrm{g} / \mathrm{kg})$ & 878.6 & 877.4 & 882.6 & 887.8 \\
\hline Crude protein $(\mathrm{g} / \mathrm{kg})$ & 201.4 & 199.0 & 196.9 & 214.1 \\
\hline Neutral-detergent fibre $(\mathrm{g} / \mathrm{kg})$ & 111.3 & 113.6 & 124.8 & 123.5 \\
\hline Ether extract $(\mathrm{g} / \mathrm{kg})$ & 33.3 & 33.1 & 64.7 & 64.8 \\
\hline$\beta$-D-glucan (g/kg) & 3.3 & 3.7 & 46.9 & 45.1 \\
\hline Arabinoxylan (g/kg) & 38.4 & 36.4 & 19.3 & 20.1 \\
\hline Net energy $(\mathrm{MJ} / \mathrm{kg})^{\dagger}$ & 9.8 & 9.8 & 9.8 & 9.8 \\
\hline Lysine $^{\ddagger}(\mathrm{g} / \mathrm{kg})$ & 10 & 10 & 10 & 10 \\
\hline Methionine and cysteine ${ }^{\ddagger}(\mathrm{g} / \mathrm{kg})$ & 6.0 & 6.0 & 6.0 & 6.0 \\
\hline Threonine $^{\ddagger}(\mathrm{g} / \mathrm{kg})$ & 6.5 & 6.5 & 6.5 & 6.5 \\
\hline Tryptophan $^{\ddagger}$ (g/kg) & 1.8 & 1.8 & 1.8 & 1.8 \\
\hline Calcium $^{\ddagger}(\mathrm{g} / \mathrm{kg})$ & 7.0 & 7.0 & 7.0 & 7.0 \\
\hline Phosphorus $^{\ddagger}(\mathrm{g} / \mathrm{kg})$ & 5.5 & 5.5 & 5.5 & 5.5 \\
\hline
\end{tabular}

${ }^{\dagger}$ Calculated from Sauvant et al. (2004).

${ }^{\ddagger}$ Calculated from Ministry of Agriculture, Fisheries and Food (1991). 


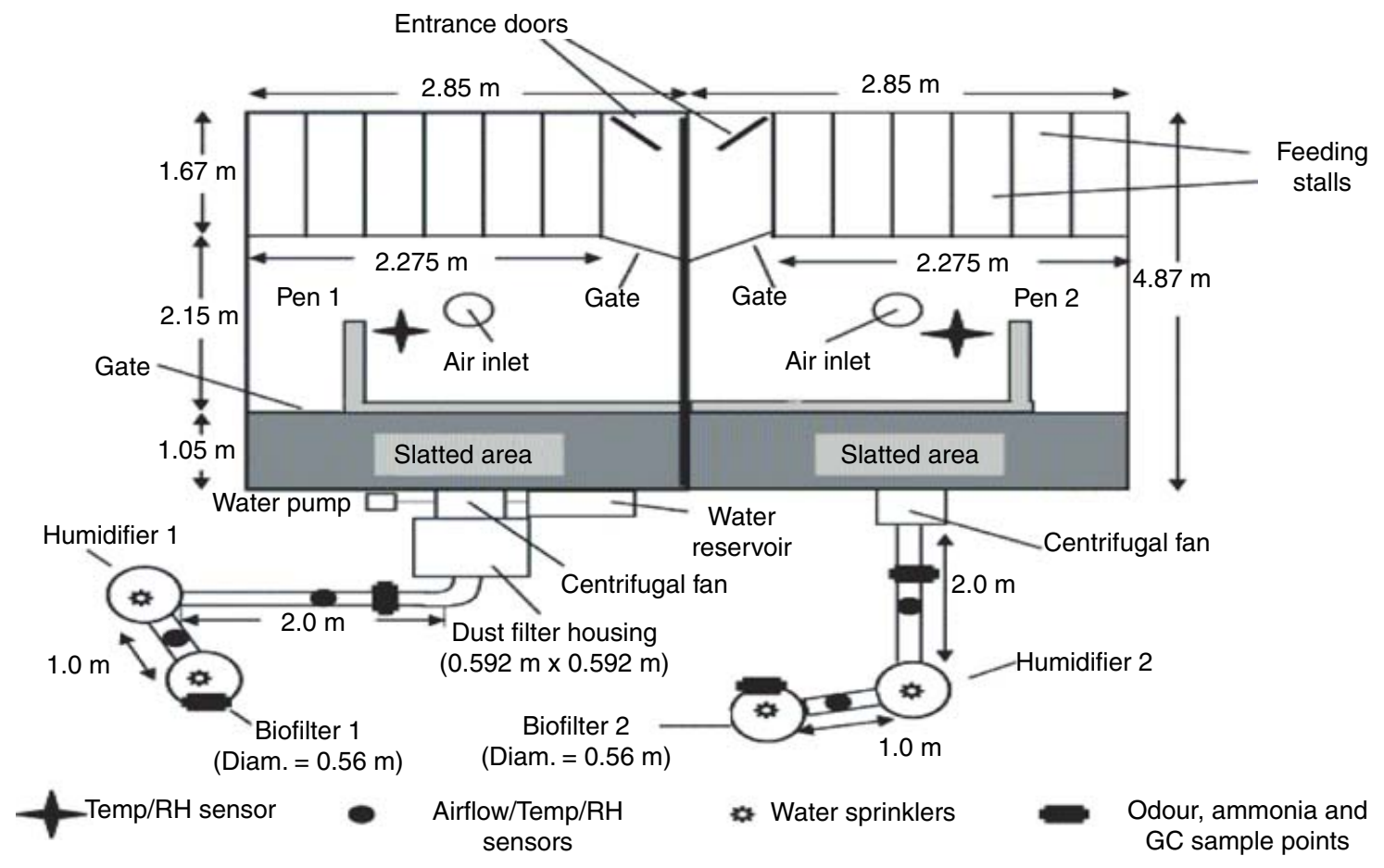

Figure 1 Design of olfactometry pens used in experiment 1.

slat:solid floor ratio) and the pigs were stocked at $0.95 \mathrm{~m}^{2}$ per pig.

Odour and ammonia emissions were measured on days 9, 11, 14, 16, 21 and 23 of each replicate period. Odour samples were collected in 20-I Nalophan bags as described by Hayes et al. (2004) and analysed for odour concentration using an Ecoma T07 dynamic olfactometer Yes/No Olfactometer (ECOMA, Honigsee, Germany). The odour threshold concentration is defined as the dilution factor at which $50 \%$ of the panellist can just detect an odour. Ammonia concentrations in the ventilation air was measured using Dräger tubes as described by Hayes et al. (2004). The pigs were individually weighed at the start and at the end of each replicate following the last recording of the ammonia and odour measurements. The odour emission rates and ammonia emission rates are presented per livestock unit (LU). One LU is equivalent to $500 \mathrm{~kg}$ body weight.

Microbiology. Eight pigs per treatment (two pigs $\times$ four replications) remained on their respective dietary treatments until slaughter. Digesta samples (approx. $10 \mathrm{~g} \pm 1 \mathrm{~g}$ ) were aseptically removed from the caecum and colon of each animal immediately after slaughter and stored in sterile containers (Sarstedt, Wexford, Ireland) on ice and transported to the laboratory within $7 \mathrm{~h}$. A $1.0 \mathrm{~g}$ sample was removed from each digesta sample, serially diluted (1:10) in $9.0 \mathrm{ml}$ aliquots of maximum recovery diluent (MRD, Oxoid, Basingstoke, UK), and spread plated $(0.1 \mathrm{ml}$ aliquots) onto selective agars, as follows. Bifidobacteria spp. were isolated on Wilkins Chalgren agar (Oxoid), containing $5 \%(\mathrm{v} / \mathrm{v})$ defribrinated blood (Biological
Labs Europe). The agar plates were subsequently incubated for 24 to $48 \mathrm{~h}$ in an anaerobic environment using a Wise Anaerobic Chamber (Don Whitley Scientific, UK) at $37^{\circ} \mathrm{C}$ with an atmosphere of $10 \%$ hydrogen, $10 \% \mathrm{CO}_{2}$ and $80 \%$ nitrogen. Suspect Bifidobacteria spp. were confirmed with API 50 CHL (BioMerieux, France). Lactobacillus spp. were isolated on de Man, Rogosa, Sharp agar (MRS, Oxoid) with overnight (18 to $24 \mathrm{~h}$ ) incubation at $37^{\circ} \mathrm{C}$ in a $5 \% \mathrm{CO}_{2}$ environment, as recommended by the manufacturers (Oxoid). The API 50 CHL (BioMerieux, France) kit was used to confirm suspect Lactobacillus spp. Enterobacteriaceae, including $E$. coli spp. were isolated on MacConkey agar (Oxoid), following aerobic incubation at $37^{\circ} \mathrm{C}$ for 18 to $24 \mathrm{~h}$. Suspect colonies were confirmed with API $20 \mathrm{E}$ (BioMerieux, France). Typical colonies of each bacterium on each agar were counted and the numbers of bacteria expressed per gram of digesta.

\section{Experiment 2: performance study}

Animals and management. Two hundred and twenty pigs (progeny of Landrace $\times$ Large White sows $\times$ Meatline boars) with an initial weight of 45 (s.d 3.0) kg were blocked on the basis of live weight and sex and within each block assigned to one of the four dietary treatments. The pigs were penned in mixed sex groups of 11 (six boars and five gilts) and were stocked at $0.95 \mathrm{~m}^{2}$ per pig with five replicates per treatment. Prior to the experiment, pigs were fed commercial diets and were approximately 14 weeks of age at commencement. Individual single space feeders with water nipples were present in all pens providing an ad libitum supply of both food and water. Animals were individually weighed at the start of the 
experiment and subsequently on day 28 and on the morning of slaughter. Feed intake was measured by recording the feed disappearance from the feeder. The performance data were analysed for the following periods: day 0 to 28 (grower), day 28 to slaughter (finisher) and day 0 to slaughter (grower-finisher).

Carcass analysis. Pigs were removed for slaughter when the pen average weight exceeded $103 \mathrm{~kg}$. Pigs were slaughtered in two batches on day 62 and day 68 of the experiment so as to minimise the variation in slaughter weight. Hot carcass weight (HCW) was recorded approximately $1 \mathrm{~h}$ post mortem. Eye-muscle depth and subcutaneous backfat was obtained by probing the right side of the carcass using a Hennessy Grading Probe (Hennessy and Chong, Auckland, New Zealand) between the third- and fourth-last ribs. The lean meat content was estimated according to the following formula (Department of Agriculture and Food (Ireland), 1994). Estimated lean meat $(\mathrm{g} / \mathrm{kg})=534.1-7.86 x+2.66 y$, where $x=$ fat depth $(\mathrm{mm}), y=$ muscle depth $(\mathrm{mm})$.

Chemical analysis of samples. Proximate analysis of diets for dry matter and ash was carried out according to Association of Official Analytical Chemists (1995). The dried concentrates were ground to pass through a $1-\mathrm{mm}$ screen (Christy and Norris hammer mill). The neutraldetergent fibre content of feed was determined using a Fibertec extraction unit (Tecator, Sweden) according to the method of Van Soest et al. (1991). The nitrogen content of the feed was determined using the LECO FP 528 instrument (Leco Instruments, Ltd, Cheshire, UK). The $\beta$-Dglucan and arabinoxylan content of the diets was measured using Megazyme kits (Megazyme, Bray, Co. Wicklow, Ireland). The $\beta$-glucanase and xylanase enzyme activity was determined approximately 4 weeks after manufacture using Megazyme kits (Megazyme, Bray, Co. Wicklow, Ireland). The $\beta$-xylanase activity of the enzyme supplemented wheat and barley-based diets was 1370 and 1450 units AXC per $g$ respectively while the $\beta$-glucanase activity of the enzyme supplemented wheat and barleybased diets was 1940 and 2090 AGL per g respectively.
Statistical analysis

In experiment 1, the data were analysed by repeated measures analysis using the Proc Mix procedure of SAS (Littel et al., 1996) using day of sampling as a repeat variable. The pen and error were the random effects and cereal, enzyme, day of sampling and the associated two- and three-way interactions were fixed, as well as replication number. In experiment 2, the data was analysed using the general linear model procedure of the Statistical Analysis Systems Institute (1985). The model used included the effect of cereal type, enzyme inclusion and the associated two-way interactions. Slaughter weight was used as a covariate for adjustment of carcass data, while initial live weight was used as a covariate for performance data.

\section{Results}

\section{Experiment 1}

Odour and ammonia emissions. The effect of dietary treatment on odour and ammonia emissions is shown in Table 2.

There was no significant cereal $\times$ enzyme $\times$ day of sampling interaction $(P>0.05)$ in either ammonia or odour. There was a significant cereal $\times$ enzyme interaction in both odour $(P<0.05)$ and ammonia concentration $(P<0.01)$ and odour $(P<0.05)$ and ammonia production $(P<0.05)$. The addition of an enzyme supplement increased odour concentration and production in the barley-based diet however enzyme inclusion had no effect in the wheat-based diet. The addition of an enzyme supplement to the barley-based diet increased ammonia concentration and production however the addition of an enzyme supplement to the wheat based diets decreased ammonia concentration and production.

Microbiology study. The effect of dietary treatment on selected faecal microbial populations are presented in Table 3. There was a significant interaction between cereal type and enzyme inclusion in the population of Enterobacteriaceae spp. $(P<0.05)$ in the caecum and Bifidobacteria spp. in the caecum $(P<0.05)$ and colon $(P<0.05)$. In the caecum, pigs offered the

Table 2 Effect of cereal type and enzyme inclusion on odour and ammonia emissions in experiment 1 (least-square means \pm s.e.)

\begin{tabular}{|c|c|c|c|c|c|c|c|c|}
\hline \multirow[b]{3}{*}{ Enzyme supplementation (E) } & \multicolumn{4}{|c|}{ Cereal type $(\mathrm{C})$} & \multirow[b]{3}{*}{ s.e. } & & & \\
\hline & \multicolumn{2}{|c|}{ Wheat } & \multicolumn{2}{|c|}{ Barley } & & \multicolumn{3}{|c|}{ Significance $^{\dagger}$} \\
\hline & - & + & - & + & & C & $E$ & $\mathrm{C} \times \mathrm{E}$ \\
\hline \multicolumn{9}{|l|}{ Odour } \\
\hline Concentration $\left(\mathrm{Ou}_{\mathrm{E}}\right.$ per $\left.\mathrm{m}^{3}\right)$ & 1271.2 & 1387.2 & 887.1 & 1399.3 & 82.3 & ns & ** & * \\
\hline Production $\left(\mathrm{Ou}_{\mathrm{E}}\right.$ per $\mathrm{s}$ per $\left.\mathrm{LU}\right)$ & 105.7 & 107.1 & 71.3 & 107.8 & 7.1 & * & * & * \\
\hline \multicolumn{9}{|l|}{ Ammonia } \\
\hline Concentration (p.p.m.) & 13.2 & 11.0 & 7.0 & 9.2 & 0.83 & $* * *$ & ns & $* *$ \\
\hline Production (g/day per LU) & 65.7 & 52.9 & 38.1 & 50.7 & 5.10 & * & ns & * \\
\hline
\end{tabular}

${ }^{\dagger}$ There was no cereal $\times$ enzyme $\times$ day of sampling interaction. ${ }^{*} P<0.05,{ }^{* *} P<0.01$, ${ }^{* * *} P<0.001$, ns non-significant. There was no main effects of day observed. 
Cereal type affects odour and ammonia emissions

Table 3 The effect of cereal type and enzyme inclusion on large intestinal microbiota in experiment 1 (least-square means \pm s.e.)

\begin{tabular}{|c|c|c|c|c|c|c|c|c|}
\hline \multirow[b]{3}{*}{ Enzyme supplement (E) } & \multicolumn{4}{|c|}{ Cereal type (C) } & \multirow[b]{3}{*}{ s.e. } & \multirow{2}{*}{\multicolumn{3}{|c|}{ Significance }} \\
\hline & \multicolumn{2}{|c|}{ Wheat } & \multicolumn{2}{|c|}{ Barley } & & & & \\
\hline & - & + & - & + & & $\mathrm{C}$ & $\mathrm{E}$ & $\mathrm{C} \times \mathrm{E}$ \\
\hline \multicolumn{9}{|c|}{ Caecum bacterial populations (expressed as $\log _{10}$ c.f.u. per g digesta) } \\
\hline Enterobacteriaceae spp. & 6.50 & 5.90 & 4.97 & 6.15 & 0.456 & ns & ns & * \\
\hline Lactobacillus spp. & 7.97 & 7.47 & 8.70 & 8.39 & 0.446 & * & ns & ns \\
\hline Bifidobacteria spp. & 6.00 & 6.82 & 7.41 & 5.30 & 0.881 & ns & ns & * \\
\hline \multicolumn{9}{|c|}{ Colon bacterial populations (expressed as $\log _{10}$ c.f.u. per g digesta) } \\
\hline Enterobacteriaceae spp. & 6.53 & 6.58 & 6.24 & 6.70 & 0.266 & ns & ns & ns \\
\hline Lactobacillus spp. & 7.84 & 7.66 & 8.99 & 8.93 & 0.749 & ** & ns & ns \\
\hline Bifidobacteria spp. & 6.51 & 7.84 & 8.31 & 6.93 & 0.750 & ns & ns & * \\
\hline
\end{tabular}

${ }^{*} P<0.05,{ }^{* *} P<0.01$, ns non-significant.

unsupplemented barley-based diet had a significantly $(P<0.05)$ lower population of Enterobacteriaceae spp. and a higher population of Bifidobacteria spp. compared with enzyme-supplemented barley diets. However, there was no effect of enzyme supplementation in wheat-based diets. Pigs offered the barley-based diets had a higher population of Lactobacilli in the caecum $(P<0.05)$ and colon $(P<0.01)$ than pigs offered wheat-based diets. In the absence of an enzyme the barley-based diet had a significantly higher population of Bifidobacteria spp. than the wheat-based diet, however, in the presence of an enzyme cereal type had no effect on Bifidobacteria spp. in the colon

\section{Experiment 2: performance study}

The effect of dietary treatment on feed intake, average daily gain (ADG), feed conversion ratio (FCR) and carcass characteristics is shown in Table 4. Neither cereal type nor enzyme supplementation had an effect on ADG or FCR during the grower period, finisher period or combined grower-finisher period. There was a significant $(P<0.05)$ cereal $\times$ enzyme interaction in feed intake during the grower period. Enzyme supplementation increased daily feed intake in the barley-based diet and decreased feed intake in the wheat-based diet. Neither cereal type nor enzyme supplementation had a significant effect on carcass characteristics

\section{Discussion}

Elevated levels of NSP, in particular the soluble fraction, can cause an increase in digesta viscosity, preventing interaction between nutrients and digestive enzymes (Campbell and Bedford, 1992) and reducing nutrient digestibility of the diets. However, decreases in ammonia emission have been reported when sources of fermentable fibre are added to the diet (Canh et al., 1998) and barley $\beta$-glucans have been shown to have pre-biotic properties ( $0^{\prime}$ Connell et al., 2005). By increasing carbohydrate fermentation and limiting protein fermentation in the large intestine, the production of some of the most offensive VFAs can be reduced (Mackie et al., 1998). The hypothesis of this study was that the anti-nutritional effects of fermentable fibre in cereals would be removed through the addition of an enzyme to the diet and pig performance would improve. However the beneficial properties of fermentable fibre could also be removed resulting in a negative effect on intestinal microflora, and odour and ammonia emission. The increase in odour and ammonia emissions from pigs offered enzyme supplemented barley-based diets compared with unsupplemented barley based-diets would support the experimental hypothesis.

The pattern of ammonia emissions in this study may have been due to differences in the microbial ecology between treatments. It was observed that the barley-based diet reduced ammonia emissions by $41 \%$ compared with the wheat-based diet. The addition of an enzyme to the barley-based diet increased ammonia emissions by $31 \%$ while the addition of the enzyme to the wheat-based diet decreased ammonia by $19 \%$. Similar results were reported by $0^{\prime}$ Connell et al. (2005) and Leek et al. (2007) using in vitro ammonia emission studies.

This reduction in ammonia emissions might have been due to the beneficial effect of the NSP in barley on the populations of bifidobacteria and lactobacilli. The inclusion of barley in the diet promotes carbohydrate fermenting bacteria (0'Connell et al., 2005). In the large intestine, these fibre-degrading bacteria utilise ammonia as a substrate for microbial protein synthesis and are subsequently excreted in the faeces. The effect of this is a shift in nitrogen excretion from urinary nitrogen to bacterial nitrogen in faeces (Nahm, 2003). This is desirable as it limits the capacity for rapid ammonia volatilisation (Mroz et al., 2000). Urinary nitrogen is excreted as urea which is converted to ammonia by bacterial ureases after mixing with faeces.

Dietary fibre also provides a non-nitrogen containing energy source to distal bacteria so that the distal nitrogen sources are used for bacterial protein synthesis rather than energy yielding ammonia (Canh et al., 1998).

In wheat-based diets the addition of an enzyme reduced the ammonia emissions significantly. Similar results were reported using in vitro ammonia emission studies. Leek et al. 
Garry, Fogarty, Curran, O'Connell, O'Doherty

Table 4 Effect of cereal type and enzyme supplementation on pig performance and carcass characteristics (least-square means \pm s.e.)

\begin{tabular}{|c|c|c|c|c|c|c|c|c|}
\hline \multirow[b]{3}{*}{ Enzyme supplementation (E) } & \multicolumn{4}{|c|}{ Cereal type (C) } & \multirow[b]{3}{*}{ s.e. } & \multirow{2}{*}{\multicolumn{3}{|c|}{ Significance }} \\
\hline & \multicolumn{2}{|c|}{ Wheat } & \multicolumn{2}{|c|}{ Barley } & & & & \\
\hline & - & + & - & + & & $\mathrm{C}$ & $E$ & $\mathrm{C} \times \mathrm{E}$ \\
\hline \multicolumn{9}{|l|}{ Daily feed intake (kg/day) } \\
\hline Grower feed intake & 1.89 & 1.79 & 1.82 & 1.91 & 0.034 & ns & ns & * \\
\hline Finisher feed intake & 2.37 & 2.37 & 2.38 & 2.39 & 0.076 & ns & ns & ns \\
\hline Grower-finisher feed intake & 2.13 & 2.08 & 2.10 & 2.15 & 0.047 & ns & ns & ns \\
\hline \multicolumn{9}{|l|}{ Average daily gain (ADG, kg/day) } \\
\hline Grower ADG & 0.867 & 0.850 & 0.822 & 0.876 & 0.022 & ns & ns & ns \\
\hline Finisher ADG & 0.895 & 0.904 & 0.905 & 0.869 & 0.030 & ns & ns & ns \\
\hline Grower-finisher ADG & 0.881 & 0.877 & 0.864 & 0.873 & 0.021 & ns & ns & ns \\
\hline \multicolumn{9}{|l|}{ Feed conversion ratio $(F C R, \mathrm{~kg} / \mathrm{kg})$} \\
\hline Grower FCR & 2.18 & 2.12 & 2.23 & 2.18 & 0.048 & ns & ns & ns \\
\hline Finisher FCR & 2.63 & 2.63 & 2.63 & 2.76 & 0.066 & ns & ns & ns \\
\hline Grower-finisher FCR & 2.41 & 2.38 & 2.43 & 2.47 & 0.041 & ns & ns & ns \\
\hline \multicolumn{9}{|l|}{ Carcass characteristics } \\
\hline Slaughter weight $(\mathrm{kg})$ & 103.4 & 103.3 & 103.4 & 103.0 & 1.40 & ns & ns & ns \\
\hline Carcass weight $(\mathrm{kg})$ & 76.9 & 76.0 & 76.4 & 76.4 & 0.75 & ns & ns & ns \\
\hline Killing-out proportion $(\mathrm{g} / \mathrm{kg})$ & 744.4 & 736.4 & 737.2 & 742.0 & 3.00 & ns & ns & ns \\
\hline Lean proportion $(\mathrm{g} / \mathrm{kg})$ & 583.0 & 584.2 & 578.7 & 583.8 & 3.75 & ns & ns & ns \\
\hline Backfat (mm) & 11.9 & 11.7 & 12.6 & 11.6 & 0.25 & ns & ns & ns \\
\hline
\end{tabular}

${ }^{*} P<0.05$, ns non-significant.

(2007) found that xylanase supplementation of wheat-based diets decreased the urine:faeces nitrogen excretion ratio in pigs resulting in a decrease in ammonia emissions. There is also evidence that xylanase supplementation of wheat-based diets increases microbial fermentation (Bedford and Schultz, 1998) which may also result in a lower slurry $\mathrm{pH}$.

The pattern of odour emissions in this study may have been due to a number of reasons. Firstly, by limiting protein fermentation and increasing carbohydrate fermentation in the large intestine, the production of some of the most offensive smelling compounds emanating from pig production can be reduced. Both protein and carbohydrate fermentation contribute to the production of acetic acid, however, the branched-chain fatty acids i.e. isobutyric and isovaleric acid are produced exclusively from protein fermentation and have a more offensive odour than the straight-chain VFAs (Mackie et al., 1998). O'Connell et al. (2005) found that the proportion of isovaleric and isobutyric acid in the caecum and colon was significantly reduced, as was the acetic acid: propionic acid ratio when pigs were fed barley-based diets compared with wheat-based diets. It appears that the reductions in isovaleric and isobutyric acid have occurred as a direct result of barley supplying a greater level of carbohydrate relative to protein to the large intestine probably because of the lower ileal digestibility of NSP in barley (Pluske et al., 2001).

Secondly, the products of carbohydrate fermentation, such as lactic acid and VFAs would also reduce the digesta $\mathrm{pH}$, creating conditions unfavourable for the growth of protein fermenting bacteria (Smith and MacFarlane, 1997). At lower $\mathrm{pH}$ values, carbohydrate-fermenting bacteria incorporate more free amino acids into microbial protein, thus further limiting the potential for ammonia volatilisation. An additional effect of this is that it reduces the availability of substrate for protein fermenting bacteria (Smith and MacFarlane, 1997), with consequential beneficial effects on odour release. Because the products of fermentation are influenced by the population of bacteria within the gut, it is imputed that the addition of an enzyme will also affect the production of these products. By suppressing the activity of carbohydrate-fermenting bacteria due to lack of substrate, a reduction in the amount of urea being incorporated into bacterial nitrogen also occurs. The ultimate effect of this is an increase in the availability of proteinaceous substrate for fermentation, with consequential increase in branched-chain fatty acid production (Hobbs et al., 1995) and increase in odour production.

The primary effect of xylanase and $\beta$-glucanase supplements is to reduce digesta viscosity. However, a reduction in digesta viscosity decreases total tract transit time and microbial proliferation resulting in a negative effect on fermentation in the large intestine (Bach Knudsen and Hansen, 1991) and on the beneficial pre-biotic properties of the $\beta$-glucan ( $0^{\prime}$ Connell et al., 2005). However, there is also evidence that xylanase supplementation promotes the growth of Bifidobacterium in pigs ( $0^{\prime}$ Connell et al., 2005) and in poultry (Bedford, 2000).

Per $\mathrm{kg}$ there was $47 \mathrm{~g} \beta$-glucans and $19.3 \mathrm{~g}$ arabinoxylan available as substrate for enzymes in the barley-based diet while there was $38 \mathrm{~g}$ arabinoxylan available for substrate in the wheat-based diets. The enzyme supplement used in this experiment was a combination of endo-1,3 (4) - $\beta$-glucanase and endo-1,4- $\beta$-xylanase and is active against $\beta$-glucans and arabinoxylans. O'Connell 
et al. (2005) found that the addition of these enzyme preparations effectively degraded the viscous NSP in the diet, leading to an enhanced nutrient digestibility, when using diets of similar composition to the diets used in the current study. However, there was no significant cereal type or enzyme supplementation effect on pig performance or carcass characteristics in the current study.

The lack of response to enzyme supplementation may have been due to the fact that the diets were formulated to have a high energy concentration and were offered to grower finisher pigs. The response to enzyme supplementation may be more evident in low energy diets using poor quality raw materials (Bedford et al., 1998) or in younger pigs (Officer, 2000). In growing-finishing pigs, the growth promoting effect of NSP-degrading enzymes supplemented to cereal diets has not been established with certainty.

In conclusion, the inclusion of an enzyme mix to barleybased diets increased odour and ammonia emissions, while the addition of an enzyme mix to wheat-based diets decreased ammonia emissions. Neither cereal type or enzyme supplementation had an effect on pig performance or carcass characteristics.

\section{References}

Association of Official Analytical Chemists 1995. Official methods of analysis, 16th edition. AOAC, Washington, DC, USA.

Bach Knudsen KE and Hansen I 1991. Gastrointestinal implications in pigs of wheat and oat fractions, 1. Digestibility and bulking properties of polysaccharides and other major constituents. British Journal of Nutrition 65, 217-232.

Bedford MR and Schultz H 1998. Exogenous enzymes for pigs and poultry. Nutrition Research Reviews 11, 91-114.

Bedford MR 2000. Exogenous enzymes in monogastric nutrition - their current value and future benefits. Animal Feed Science and Technology 86, 1-13.

Bedford MR, Scott TA, Silversides FG, Classen HL, Swift ML and Pack M 1998. The effect of wheat cultivar, growing environment and enzyme supplementation on digestibility of amino acids by broilers. Canadian Journal of Animal Science 78, 335-342.

Campbell GL and Bedford MR 1992. Enzyme applications for monogastric feeds: a review. Canadian Journal of Animal Science 72, 449-466.

Canh TT, Sutton AL, Aarnink AJA, Verstegen MWA, Schrama JW and Bakker GCM 1998. Dietary carbohydrates alter the faecal composition and pH and the ammonia emission from slurry of growing pigs. Journal of Animal Science 76, 1887-1895.

Close WH 1994. Feeding new genotypes: establishing amino acid/energy requirements. In Principals of pig science (ed. DJA Cole, J Wiseman and MA Varley), pp. 123-140. Nottingham University Press, Nottingham, UK.

De Lange CMF 2000. Characterisation of non-starch polysaccharides. In Feed evaluation- principals and practice (ed. PJ Moughan, MWA Verstegen and MI Visser-Reyneveld), pp. 77-92. Wageningen Pers, Wageningen, The Netherlands.

Department of Agriculture and Food (Ireland) 1994. Pig carcass dressing specification SI 216.
Dierick $\mathrm{N}$ and Decuypere J 1996. Mode of action of exogenous enzymes in growing pig nutrition. Pig News Information 17, 41N-48N.

European Council 2001. Commission regulation (EC) no. 418/2001 of 1 March 2001 concerning the authorisation of new additives and uses of additives in feedingstuffs. Official Journal of the European Communities L 62, 2.1.2001.

Hayes ET, Leek ABG, Curran TP, Dodd VA, Carton OT, Beattie VE and O'Doherty JV 2004. The influence of diet crude protein level on odour and ammonia emissions from finishing pig houses. Bioresource Technology 91, 309-315.

Hobbs PJ, Misslebrook TH and Pain BF 1995. Assessment of odours from livestock wastes by a photoionization detector, an electronic nose, olfactometry and gas chromatography-mass spectrometry. Journal of Agricultural Engineering Research 60, 137-144.

Leek ABG, Callan JJ, Reilly P, Beattie VE and O'Doherty JV 2007. Apparent component digestibility and manure ammonia emission in finishing pigs fed diets based on barley, maize or wheat prepared without or with exogenous non-starch polysaccharide enzymes. Animal Feed Science and Technology (available on line).

Littel RC, Milliken GA, Stroup WW and Wolfinger RD 1996. SAS system for mixed models. SAS Institute Inc., Cary, NC.

Mackie RI, Stroot PG and Varel VH 1998. Biological identification and biological origin of key odour compounds in livestock waste. Journal of Animal Science 76, 1331-1342.

Ministry of Agriculture, Fisheries and Food 1991. The feedingstuffs regulations 1991. Statutory instrument no. 2840, 9.76. Her Majesty's Stationery Office, London.

Mroz Z, Moeser AJ, Vreman K, van Diepen JTM, van Kempen T, Canh TT and Jongbloed AW 2000. Effects of dietary carbohydrates and buffering capacity on nutrient digestibility and manure characteristics in finishing pigs. Journal of Animal Science 78, 3096-3106.

Nahm KH 2003. Influence of fermentable carbohydrates on shifting nitrogen excretion and reducing ammonia emission of pigs. Critical Reviews in Environmental Science and Technology 30(2), 165-186.

Officer DI 2000. Feed enzymes. In Farm animal metabolism and nutrition (ed. JPF D'Mello), pp. 405-421. CABI Publishing, Wallingford, UK.

O'Connell M, Sweeney T, Callan JJ and O'Doherty JV 2005. The effect of cereal type and exogenous enzyme supplementation in pig diets on nutrient digestibility, intestinal microflora, volatile fatty acid concentration and manure ammonia emissions from pigs. Animal Science 81, 357-364.

Pitcairn CER, Skiba UM, Sutton MA, Fowler D, Munro R and Kennedy V 2002. Defining the spatial impacts of poultry farm ammonia emissions on species composition of adjacent woodland groundflora using Ellenberg Nitrogen Index, nitrous oxide and nitric oxide emission and foliar nitrogen as marker variables. Environmental Pollution 119, 9-21.

Pluske JR, Kim JC, McDonald DE, Pethick DW and Hampson DJ 2001. Non-starch polysaccharides in the diets of young piglets. In The weaner pig: nutrition and management (ed. MA Varley and J Wiseman), pp. 81-111. CAB International, Wallingford, Oxon, UK.

Sauvant D, Perez JM and Tran G 2004. Tables of composition and nutritional value of feed materials. Wageningen Academic Publishers, The Netherlands and INRA, Paris, France.

Smith EA and MacFarlane GT 1997. Dissimilatory amino acid metabolism in human colonic bacteria. Anaerobe 3, 327-337.

Statistics Analysis Systems Institute 1985. Statistical analysis systems version 6.12. SAS Institute Inc, Cary, NC.

Van Soest PJ, Robertson JB and Lewis BA 1991. Methods of dietary fibre, neutral detergent fibre, and non-starch polysaccharides in relation to animal nutrition. Journal of Dairy Science 74, 3583-3597. 